\title{
Assessing Poiesis as an Effective Approach to Integrating Music and Visual Art
}

\author{
Janel G. Bauza-Wahiman \\ Faculty of the College of Music, University of the Philippines \\ Diliman, Quezon City 1101, Philippines \\ e-mail: upmued@gmail.com
}

Published online: 10 August 2018

Cite this article (APA): Bauza-Wahiman, J.G. (2018). Assessing Poiesis as an effective approach to integrating music and visual art. Malaysian Journal of Music, 7, 20-37.

\begin{abstract}
This study aims to assess the effectiveness of Poiesis as an approach to integrating music and visual art. It uses the descriptive inquiry approach making use of qualitative research instruments and qualitative data analysis techniques. Data was collected through interviews, observation, examination of audiovisual materials and student reflections. Data was analysed using the coding process, yielding the following themes: 1) opportunities for socialisation in the project; 2) developing appreciation for the two disciplines and for the creative process; 3 ) personal growth through the project; and 4) growth as an artist through the project. Data from the interviews, observations and reflections tallied with some of the themes that emerged from the audio-visual materials. This means that the collaboration project is effective in exhibiting the connection between the two disciplines and in providing holistic learning for its participants.
\end{abstract}

Keywords: arts, effective, integration, music, teaching strategy, visual art

\section{Introduction}

The analogous approach toward teaching the arts is based on the premise that elements and principles are shared across the visual art, music, literature, theater and dance (Campbell \& Scott-Kassner, 2010). For example, the elements of music in the field of music correspond to the elements of design in visual art. Both disciplines share principles such as tension and release, repetition and contrast, balance and symmetry. This analogous approach leads to an even deeper and more 
comprehensive understanding and appreciation of each of these disciplines. The steady escalation of integrative learning in the 20 ${ }^{\text {th }}$ century (Bresler, 1995) eventually led the National Association for Music Education (NAfME) to decide to include two interdisciplinary standards in its National Standards for music education in basic education. These standards were updated in its 2014 edition as: 1) Standard No. 8 - understanding relationships between music, the other arts, and disciplines outside the arts and 2) Standard No. 9 - understanding music in relation to history and culture (Vazquez, 2014; National Association for Music Education, 2014). These standards were integrated into the Philippine educational system through different innovations in the basic education curriculum. For example, the Makabayan curriculum (2002) integrated five different learning areas: Social Studies; Geography, History and Civics; Music, Art and Health; Home Economics; and Values Education. The MAPEH (2003) brought together Music, Art, Physical Education and Health subjects. The K-12 curriculum (2013) merged Music and Art subjects together (Government of the Republic of the Philippines, Department of Education, 2002, 2003, 2013).

Poiesis is a music and art collaboration project touching on integrative learning of the arts. It integrates the arts as an approach in teaching. Poeisis is a collaboration project between the University of the Philippines' College of Music, Music Education Department and the College of Fine Arts, Visual Communication Department. This project brings together the Introduction to Music Education and Visual Perception courses. Poiesis was conceptualised by Joy Timbol Guadalupe and Mitzi Marie Aguilar Reyes with the intent of fostering educational exchange and cultural experience among the students. The project provides opportunities for interaction, free exchange of ideas and also enhances students' knowledge and artistic talents within their disciplines and to discover how the curricular offerings complement each other (Reyes, 2010). The purpose of this study is to investigate whether Poiesis is an effective approach to integrating music and visual art.

\section{Literature Review}

The term 'poiesis' has its root in the word 'poetry', first introduced by Aristotle. In a general way, it means 'to produce' (Balaban, 1990; Greenberg, 1961; Jauss \& Shaw, 1982; Marini, 2014; Whitehead, 2003). Matusov \& Marjanovic-Shane (2012) believe it to sometimes mean 'to reproduce' since conventional schooling tends to strongly influence children to merely reproduce what is 'culturally given as appropriate' instead of encouraging them to influence and determine what can be deemed as' appropriate culturally' (Matusov \& Marjanovic-Shane, 2012, p. 165). The core of Poiesis is to provide music and fine arts students with a venue for producing creative expressions in the context of collaboration with fellow budding artists. The collaboration consists of three phases: 1) the music students produce recordings of their original compositions; 2) the fine arts students interpret those music pieces into original paintings, and both music and visual art are showcased in a culminating activity; and 3) another batch of music students interpret those same paintings and original compositions. These new creations are performed at another 
culminating activity. Technical and aesthetic production is embodied in this particular collaboration project.

To illustrate the Poiesis process, here is the step-by-step scenario:

1. For the first semester of the academic year, music students compose a 3-minute original composition (either based on a theme agreed on by the class or based on free, personal expression) and are recorded.

2. The music professor collates these recordings and turns them over to the fine arts class.

3. The fine arts professor randomly assigns music compositions to her students.

4. A meet-up is arranged between the music and fine arts classes. In this meeting, a short lecture on the parallel elements and principles between music and visual art is given. At the same time, composers and artists are given a chance to get to know each other and to ask each other about the compositions.

5. A visual interpretation of the music is created, something like the samples in Figure 1 and Figure 2.

6. Each painting is showcased while each of the original music is performed live by the composer in a culminating activity.

For the second semester of the academic year, the process is reversed:

1. The paintings from the first semester (such as the ones shown above) are randomly assigned to another batch of music students, who then interpret them into original 3-minute compositions.

2. Another meet-up is arranged in which the same lecture on the parallel elements and principles between the two disciplines is given and in which artists and composers may discuss the artworks with each other.

3. A music interpretation of each painting is composed. A couple of samples of original music may be accessed through this link: https://drive.google.com/drive/folders/1NDxFSDQ_WakF9rNAniIW7GuYu wsd740N?ogsrc $=32$

4. Again, each painting is showcased while each of the original music is performed live by the composer in a culminating activity. 


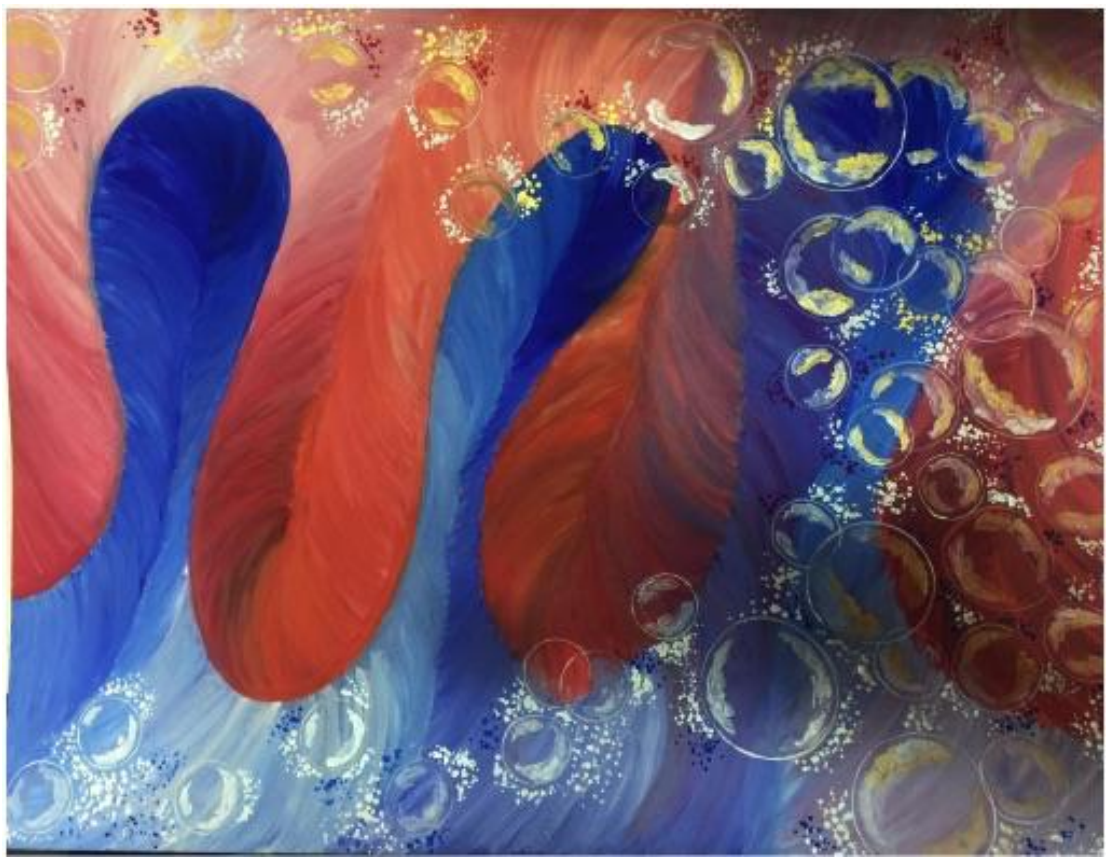

Figure 1. Sample Painting 1 (Danica Garchitorena, 2017)

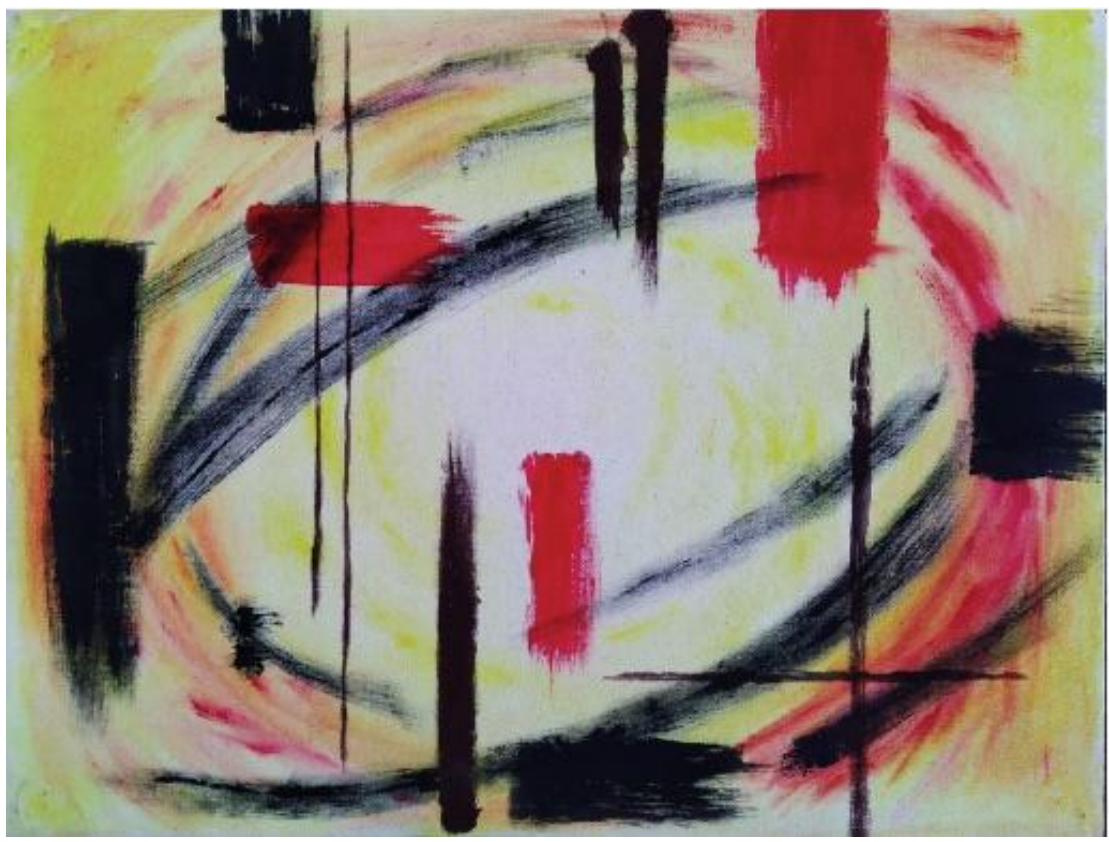

Figure 2. Sample Painting 2 (Danielle Canales, 2017) 
The Poiesis project provides students with hands-on opportunities to interact with the concepts of the two disciplines. It is an opportunity for experiential learning and affords a venue for social interaction and collaboration among the students. The framework for curricular integration lies on theories of child development, learning theories, and the aim of education to provide a holistic development of good citizens in society (Coudriet, 2013). Poesis is a teaching approach that facilitates student interaction with and appreciation for the interrelationship of various subject areas in one particular context or venue (Bresler, 1995; Coudriet, 2013; Irwin \& Reynolds, 1995; Wiggins, 2001). It has its roots in Greek formal education - specifically, in the philosophy of Socrates and Plato (Coudriet, 2013).

At the beginning of the $20^{\text {th }}$ century, progressive educators campaigned for a child-centered curriculum and holistic learning. This greatly promoted the idea of integration among subjects in the curriculum (Bresler, 1995; Huang, 2012; Irwin \& Reynolds, 1995; Mosley, 2014; Thompson, 2015). With additional contributions by Benjamin Bloom (three domains of learning) and Howard Gardner (theory of multiple intelligences), an enthusiastic advocacy for finding connections among other disciplines to enhance and deepen student learning, gained much momentum (Coudriet, 2013; Mosley, 2014). Experts heralded the benefits of integration, stating that it possesses great potential in positively impacting student learning and "teachers who integrate learning for their students are providing access to various skills, media and methods while simultaneously fostering a sense of community for their learners" (Coudriet, 2013, p. 57). Bresler (2011) claims that integration is a manifestation of educational entrepreneurship (p. 10). Teachers may also exhibit entrepreneurial qualities such as risk-taking, creativity, industriousness, persistence and commitment to usefulness that bring about change in students' lives. Thus, integrating the curriculum may bring a positive impact on student learning. Furthermore, opting for an integrated curriculum is a giving up of the safety of the disciplines and prescribed materials, a crossing of disciplinary borders and a reconsideration of what is important, a focus on important issues rather than on traditional ways of organising knowledge, undertaking work that goes beyond conventional, well-established understanding of knowledge (p. 12). Through integration, educators not only create a new path for learning to take place but also provide opportunities for students to learn various content areas at one time as well.

Integration successfully penetrated the arts curriculum after the place of the arts in Education had been justified through the works of Harry Broudy and Elliott Eisner (Bresler, 1995; Bresler, 2002; Huang, 2012; Mosley, 2014; Thompson, 2015). In the 1990s, when the value of the arts began to be challenged, the Music Educators' National Conference or MENC (now known as NAfME) issued a bulletin called, 'A Vision for Arts Education in the $21^{\text {st }}$ Century'. This reiterated how the arts can be "taught in an interdisciplinary manner as part of the broader curriculum and can make immense contributions to the teaching of other disciplines" (Bresler, 1995, p. 3). In support of this, a growing body of research exists that shows the effectiveness of integration in improving students' performance in school even as educators observe it as beneficial for students academically, behaviourally and emotionally (Bresler, 2002; Campbell \& Scott- 
Kassner, 2010; Hartle, Pinciotti \& Gorton, 2015; Huang, 2012; Irwin \& Reynolds, 1995; Marshall, 2010; Mosley, 2014; Thompson, 2015). At the same time, however, some studies suggest that there is no strong evidence of the direct causal relationship between integration of the arts and academic achievement (Huang, 2012).

Different models of integration can be used in the classroom setting. There are four models formulated by arts advocates - advocates of music, specifically. As elaborated by Huang (2012), these four advocates are: 1) Bresler (1995); 2) Burton (2001); 3) Snyder (1996); and 4) Wiggins (2001). While differing terminologies are used in these advocates' models, common among the components of the models are the following:

1. Integration in which one discipline serves merely as a tool to enhance or reinforce learning of another discipline;

2. Integration in which the integrity and uniqueness of each of the disciplines is preserved and equally given importance;

3. Integration in which connections of common, greater themes or content are made across disciplines;

4. Integration in which common processes and skills are highlighted across disciplines; and

5. Integration in which social interaction is the goal, a way to connect with communities through partnerships and projects.

An examination of these different models of integration reveals that what is most relevant to the context of this study are the second, third, fourth and fifth styles. This is due to the fact that the project is made in the university level of education in which specialisation of each discipline is the goal. Additionally, the fifth style is reflected and cultivated in the social interaction among students from the two different colleges during the coordination stage of the project and during the culminating activities. In particular, a small, simple potluck is arranged after the culminating activities to give the students additional opportunities for interaction with each other.

At this point, it is to be noted that the success and effectiveness of integration hinge on several factors, the most prominent of which are teacher expertise, teacher qualities, collaboration among teachers involved and sufficient time for planning (Bresler, 2011; Campbell \& Scott-Kassner, 2010; Coudriet, 2013; Galeazzi, 2015; Huang, 2012; Hulstrand, 2012; Vazquez, 2014). Along with Bloom's three domains of learning as a framework for assessing learning, these are the criteria in gauging how effective Poiesis is as an approach to teach about music and visual art.

\section{Methodology}

This study examines the effectiveness of Poiesis as an approach toward integrating music and visual art. The researcher utilised two approaches for the study. First, this researcher tried to understand the nature of the participants' subjective experiences 
of the collaboration project, a method based on social constructivism. Secondly, the inductive approach was used to make an interpretation of the individual experiences of the participants as a whole. Then a conclusion was drawn on the project's effectiveness.

The study follows a descriptive inquiry making use of qualitative research instruments and qualitative data analysis techniques. Purposeful sampling refers to qualitative sampling in which researchers intentionally select individuals and sites that can provide a rich repository of information to answer the particular research question at hand (Creswell, 2012). Among the various purposeful sampling techniques, the researcher chose homogeneous sampling because this sampling occurred before data collection and the participants were selected based on similar background such as learning experience through Poiesis. Data was collected through interviews, direct observations, documents (audio-visual materials) and student reflection. The researcher also triangulated the information acquired to affirm the credibility of the findings.

Below are the questions used in the reflection sheets and interviews.

Table 1

Questions on the Reflection Sheets

\section{Reflection on Poiesis: A Music and Visual Art Presentation}

1. How do you feel about this course requirement? Which part of it did you like? Dislike? Why?

2. Describe something you learned as a result of this experience.

3. Did this activity help you learn more about music and visual art? How?

4. How was the concept of music and visual art integration reflected in this course requirement?

Table 2

Interview Questions

1. Did you like Poiesis?

2. Did Poiesis help you understand and appreciate the arts more? How?

3. What did you learn about music and visual art through your participation in Poiesis?

The first step of analysis was to explore the data through reading and optically scanning through the whole text and videos to get an overview of all the responses and material. The second step was the coding process, which involved segmenting and labelling the text to identify emerging themes in the data. The table below illustrates the coding process: 
Table 3

The Coding Process

\begin{tabular}{ccccc}
$\begin{array}{c}\text { Initially read } \\
\text { through text } \\
\text { data }\end{array}$ & $\begin{array}{c}\text { Divide the text } \\
\text { into segments of } \\
\text { information }\end{array}$ & $\begin{array}{c}\text { Label the } \\
\text { segments of } \\
\text { information with } \\
\text { codes }\end{array}$ & $\begin{array}{c}\text { Reduce overlap } \\
\text { and redundant } \\
\text { codes }\end{array}$ & $\begin{array}{c}\text { Collapse codes } \\
\text { into themes }\end{array}$ \\
$\downarrow$ & $\downarrow$ & $\Downarrow$ & $\downarrow$ & $\downarrow$ \\
\hline $\begin{array}{c}\text { Many pages of } \\
\text { text }\end{array}$ & $\begin{array}{c}\text { Many segments } \\
\text { of text }\end{array}$ & $30-40$ codes & $\begin{array}{c}\text { Codes reduced } \\
\text { to 20 }\end{array}$ & $\begin{array}{c}\text { Codes reduced } \\
\text { to 5 - 7 themes }\end{array}$ \\
\hline
\end{tabular}

Table 4

Researcher's Observation Notes

\begin{tabular}{|c|c|}
\hline Observations & Reflections \\
\hline \multicolumn{2}{|l|}{ Poiesis $-1^{\text {st }}$ batch run } \\
\hline $\begin{array}{ll}-\quad & \text { very informal program } \\
\text { - } & \text { artists verbally described their } \\
\text { artworks } \\
\text { musicians provided } \\
\text { explanations/short descriptions of } \\
\text { their work as well } \\
\text { - } \quad \text { a lot of chattering and giggling of } \\
\text { the participants, signifying [having } \\
\text { fun] in the event } \\
\text { - } \quad \text { ppositive atmosphere] during the } \\
\text { event and [positive response] of the } \\
\text { participants about continuing the } \\
\text { project }\end{array}$ & $\begin{array}{l}\text { Some of the paintings 'make sense' to me - } \\
\text { i.e., I could clearly 'see' the [connection] of } \\
\text { the elements in the artwork and the } \\
\text { soundscape of the music - while others } \\
\text { don't. }\end{array}$ \\
\hline \multicolumn{2}{|l|}{ Poiesis $-2^{\text {nd }}$ batch run } \\
\hline $\begin{array}{l}\text { varied genres and styles of music } \\
\text { compositions - classical sounding, } \\
\text { 'high art', pop, Asian, fusion, jazz, } \\
\text { etc. } \\
\text { first time to feature paintings and } \\
\text { kinetic typography at the same time } \\
\text { from the Fine Arts majors } \\
\text { - } \quad \text { humour and creativity could clearly } \\
\text { be seen at the artworks } \\
\text { - laughing (both from performers and } \\
\text { audience/participants) signifies } \\
\text { [enjoyment and fun] }\end{array}$ & $\begin{array}{l}\text { For me, the 'success' of the event depends } \\
\text { on the proficiency and musicality of the } \\
\text { musicians, as well as on the [stage } \\
\text { presence/presentation skills] of all involved. } \\
\text { Also, the program and 'flow' of the } \\
\text { performers should be 'seamless'. }\end{array}$ \\
\hline
\end{tabular}


This is my favourite batch of music compositions so far - the level of artistry of the music, as well as the lyricism of the melodies, added to the [aesthetic pleasure].

Still, there is a lot to be had for the flow/'seamlessness' of the program. I find the lulls in between numbers such a drag.

Especially when the music is Asian, it's difficult for me to find the [connection] Poiesis $-4^{\text {th }}$ batch run
$-\quad$ The stage presence of the Fine Arts majors is improving - the flow of the program is getting better

- Instead of descriptions about their artworks, artists recite a haiku, adding another level of creativity and artistry to the project.

Poiesis $-5^{\text {th }}$ batch run

Poiesis $-6^{\text {th }}$ batch run

Indeed, differing levels of [creativity] of students are showcased through this activity.

I really believe that through this project, students are 'forced' to delve into the technical elements and principles of both disciplines in order to fulfill the requirement. As such, a deeper [understanding and appreciation] of both Music and Art is achieved. Indeed, students have an opportunity to 'see' and experience the [connection] between the two disciplines.

Poiesis $-7^{\text {th }}$ batch run
$-\quad$ Very [creative] pieces from Composition majors, employing various sound sources in avantgarde style

- Particularly liked the piece called, 'Wala Nang Slots?!' It is a perfect 'sound representation' of the sentiments of students during the enrollment period 
Table 5

Summary of Code Words and Themes

\begin{tabular}{|c|c|}
\hline Code Words & Emerging Themes \\
\hline Collaborative & \multirow[t]{2}{*}{ Social aspect of the project } \\
\hline Social interaction & \\
\hline Expressivity and subjectivity of art & \multirow[t]{4}{*}{ Developing appreciation } \\
\hline Appreciation for the arts & \\
\hline Connectedness of music and visual art & \\
\hline $\begin{array}{l}\text { Open-mindedness and appreciation for } \\
\text { others and others' point of view }\end{array}$ & \\
\hline $\begin{array}{l}\text { Self-discipline, appreciating order and } \\
\text { structure and creativity }\end{array}$ & Personal growth \\
\hline $\begin{array}{l}\text { Learning to judge/evaluate interpretation, } \\
\text { finding own identity and style, acquisition of } \\
\text { additional skills, self-discovery, } \\
\text { improvement of technique }\end{array}$ & \multirow[t]{4}{*}{ Personal growth and growth as an artist } \\
\hline $\begin{array}{l}\text { Experience of the creative process, the art } \\
\text { form itself }\end{array}$ & \\
\hline Creativity & \\
\hline $\begin{array}{l}\text { Understanding, meaning-making, forming } \\
\text { vocabulary to describe }\end{array}$ & \\
\hline
\end{tabular}

Table 4 is this researcher's observation notes in each of the Poiesis batch runs for the past seven years. The words in brackets are the text segments that were reduced into codes and then themes later on. After reading through the whole text to get an overview, the researcher proceeded to the third step, which was to identify text segments by placing a bracket around them and assigning labels or code words that describe the text segments. These code words were reduced and then collapsed further by grouping similar codes together and removing redundant ones (See Table 5). This technique of coding was based on Creswell (2012) who called these similar codes 'themes'; for example, "similar codes aggregated together to form a major idea" (Creswell, 2012). Table 5 shows the table of code words and themes taken from the participants' responses in the reflection sheets, the interviews and from this researcher's observation notes.

Based on the themes that emerged, the effectiveness of the Poiesis project approach was readily determined vis-à-vis criteria found in related literature and studies. The results of this study may be used as a resource either for program or training sessions or for mentoring programs of university faculty for in-service music and visual art teachers.

\section{Findings and Discussion}

Participants of this study were students from the Introduction to Music Education and Visual Perception classes. They have also taken part in Poiesis for 
the past seven years that it has been run. The author analysed and assessed the interviews, student reflections, audio-visual materials and direct observations collected within the 2016-2017 academic year. A summary of these participants' responses is shown in Table 6 below.

Table 6

Summary of Participants' Responses in the Interviews and Reflection Sheets

Poiesis

\begin{tabular}{l|l}
\hline \multicolumn{1}{c|}{ Activity } & \multicolumn{1}{c}{ General Response of Participants } \\
\hline music & $\begin{array}{l}\text { Participants felt challenged, especially that most of them had to do } \\
\text { it for the first time in their lives, but they developed a deeper } \\
\text { appreciation for the creative process during the course of the } \\
\text { project. } \\
\text { Participants also appreciated seeing and experiencing first-hand the } \\
\text { connectedness of music and visual art. }\end{array}$ \\
\hline $\begin{array}{l}\text { Meet-up and } \\
\text { Coordination }\end{array}$ & $\begin{array}{l}\text { Participants found that meeting up with fellow artists and working } \\
\text { with them in creating an artistic product was fun and enjoyable, } \\
\text { although there are challenges in their dealing with each other's } \\
\text { differences of perspective and interpretation. }\end{array}$ \\
\hline Creation of paintings & $\begin{array}{l}\text { Most of the participants appreciated the creative process all the } \\
\text { more. } \\
\text { Participants also appreciated their discovery of their own personal } \\
\text { style, preference and identity as artists. }\end{array}$ \\
\hline Culminating activity & $\begin{array}{l}\text { Participants gained a deeper appreciation for the arts and for the } \\
\text { power of the arts. } \\
\text { Participants also gained a deeper appreciation for and openness to } \\
\text { the diversity and depth of perspective and interpretation of fellow } \\
\text { artists. } \\
\text { Participants realised and appreciated their personal growth through } \\
\text { the project; for example, developing a sense of who they are as } \\
\text { artists, developing self-confidence in presenting something, etc. }\end{array}$
\end{tabular}

Interview questions and reflections focused on how the students felt about taking part in the project, what they learned from the experience and whether they understood more about music and art through the whole process. From data collected after the culminating activities in the first and second semesters of the 2016-2017 academic years, a total of 53 students involved in different batch runs of Poiesis participated in this study. Data with member checking right at the outset of the interviews and analysis of the answers on the reflection sheets initially yielded 11 codes. Upon further analysis, these were merged into four outstanding themes. The four themes are: 1) the opportunities for socialisation through the project; 2) the development of appreciation; 3) personal growth through the project; and 4) growth as an artist through the project. Each of the themes is discussed below. 
Table 7

Summary of Participants' Responses in the Videos and Observation Notes

Poiesis

\begin{tabular}{c|l}
\hline \multicolumn{1}{c}{ Activity } & \multicolumn{1}{c}{ General Response of Participants } \\
\hline Culminating activity & $\begin{array}{l}\text { Laughter and whoops to cheer classmates on while onstage signify } \\
\text { that the participants are having fun and enjoying the activity. This } \\
\text { can be evidence that they appreciate the project and the tasks } \\
\text { required in the project. }\end{array}$ \\
$\begin{array}{l}\text { Participants participated enthusiastically in the activity, as } \\
\text { evidenced by their works. The connectedness of music and visual } \\
\text { art may literally be seen and heard during the activity, and this may } \\
\text { signify the participants interaction with and analysis of the } \\
\text { technical elements and principles of both disciplines. } \\
\text { Participants creative output can be evidence of the maturity } \\
\text { necessary for the artistic process in producing such an output. How } \\
\text { the participants carried themselves onstage as presenters may also } \\
\text { be evidence of such maturity. }\end{array}$
\end{tabular}

\section{Socialisation}

Almost all of the respondents gave a positive response to how they felt about doing Poiesis, except two fine arts majors. These two participants specifically did not like the project because they had to paint their interpretations - and working with paint was not their forte. The issue is due to self-efficacy then and not with the particular project in general. Most of the responses from the other students were that the project was a fun and exciting course requirement. What they were most positive about was the social aspect of the project - they were able to meet new people, collaborate with fellow artists and develop social skills such as cooperation, coordination, negotiation, compromise, etc.

\section{Appreciation}

The students said they acquired a deeper appreciation for the arts, particularly for their subjectivity, their power to express multidimensional aspects, an appreciation for their fundamentals, basic principles and techniques, and the power of art to elevate one to a higher level of consciousness. The students also said that they acquired an awareness and appreciation of the connection between music and visual art, as observed in the integrated interpretations of the music and artworks themselves. Related to this is the students' appreciation for how the project fostered a deeper appreciation of the creative process involved in producing a product worthy to be deemed as 'art.' Even so, one fine arts student voiced his uncertainty about whether 'Poiesis' helped him learn about music and visual art at all. The rest of the 53 participants were much enthused about developing a deeper appreciation for the arts through the collaboration project. 


\section{Personal growth}

What was also dominant among the responses was that the students saw their personal growth through their involvement in the project. A majority of them saw an increase of open-mindedness in themselves as they learned to appreciate others and others' point of view and interpretation through the collaboration. Others highlighted their developing self-confidence in the aspect of presenting something and performing onstage. And then a few others developed self-discipline as they learned to appreciate order and structure through the deadlines for the submission of works.

\section{Growth as an artist}

One other particular theme among the responses was the students' realisation of their growth as an artist through Poiesis. Principal in the aspects of this growth is the students' self-discovery - they learned more about themselves in terms of their unique and distinct style as a composer. They discovered what their sense of purpose is as artists, and the learning style they preferred. In other words, students stated how they found out more about their own identity and style as artists through the collaboration project. As they discovered more about themselves, the students also stated that they learned to evaluate and make judgments about others' interpretations as well as about their own. This pushed them to improve on their individual technique and creativity at the same time, and to acquire additional skills that became necessary during the process of fulfilling the project. One such skill is what may be called presentation skills or proper performance etiquette such as that of exuding confidence, having good stage behaviour, appropriating the needed body gestures and facial expressions at appropriate times, establishing good eye contact and rapport with the audience and having good physical appearance (Andreas, Sloboda \& Woody, 2007). This goes for both the music and fine arts students, as the fine arts students had to present and give a short description of and a haiku (originally a Japanese poem, but may be an English poem of 17 syllables, in three lines of five, seven and five) about their artwork onstage during the culminating activity.

Thus far, data from both the interviews and student reflections show mostly a positive effect on the students involved in Poiesis, based on the four outstanding themes that emerged. A look at the themes from the videos and observation notes corroborate some of the themes from the interviews and student reflections. In the videos, the reactions of the audience (mostly made up of classmates, parents and a few faculty) were captured, the most obvious being laughter - signifying enjoyment - and whoops to cheer classmates on while onstage. This confirms that a majority of the participants, indeed, found the collaboration project fun and enjoyable, signifying their appreciation of the project and of the tasks in the project. The same was also recorded in this researcher's observation notes.

Also seen in the videos and observation notes are themes on the connectedness of music and visual art. In the videos, one is able to replay and once again witness the interrelation between the soundscapes in the music pieces and the 
artworks showcased during the culminating activity. This researcher's observation notes recorded that through this project, students were forced to delve into the technical elements and principles of both disciplines in order to fulfil the requirements of the project. A deeper understanding and appreciation of both music and visual art was achieved. Truly, students have an opportunity to see and experience the connection between the two disciplines. However, it was also noted that there is a challenge in finding the connection between the music and the artwork when the genre of the composition is Asian music. No scientific explanation can be conjured for this, only a speculation that this perception and interpretation could be due to the heavy Western orientation in music that this researcher grew up with.

This researcher's comments in the observation notes on the creativity of the students in their ability to produce works of art and on how they carried themselves onstage tallied with the theme on growth as an artist. Specifically, this researcher noted that the success of the event depends not only on the proficiency and musicality of the musicians, but also on the stage presence and presentation skills of all involved. Indeed, differing levels of creativity of students are showcased through Poiesis.

Applying Bloom's three domains of learning as framework to assess what the participants learned during the project revealed that learning in the affective domain was considerably more dominant than the cognitive learning of music and visual art concepts. For the cognitive aspect, what students said in the interviews and reflection sheets was that they learned to see and experience hands-on the connectedness of the elements and principles of the two disciplines as well as the development of their creativity in producing their works. In the videos and observation notes, the evidence for this was the music and paintings themselves that the music and fine arts students showcased. For psychomotor, both the music and fine arts students attested in the interviews and reflection sheets to the development of technique, such as mixing colours, improving their music skills, discovering their preferred styles, etc. The videos and observation notes recorded the students' overall performance and is evidence of this learning experience. And for the affective domain, mainly developing appreciation and the acquisition of certain values emerged from the responses of the students in the interviews and reflection sheets. The response of the audience and students during the culminating activity and the performance of each of the students onstage bring about a similar conclusion.

In summary, the results indicate that while learning in all three domains did take place through the Poiesis project, the responses of the participants showed that learning occurred mainly in the affective domain (that which has to do with values, appreciation and emotions). The positive responses from both music and fine arts students and the positive reactions of audiences and performers as recorded in the videos and observation notes indicate that the integration of music and visual art in Poiesis has been effective in bringing about a positive impact to all those involved. One may surmise, then, that behind-the-scenes matters such as teacher expertise, teacher qualities, collaboration among teachers involved and sufficient time for planning must have occurred for the collaboration project to receive such positive feedback and to be running continuously for more than seven years now. 


\section{Conclusion}

The purpose of this study was to assess whether Poiesis is an effective approach in integrating and in teaching about music and visual art. Different data collection instruments were employed in order to yield and cross-check the validity of the findings. Some of the four outstanding themes garnered from the interviews and reflection sheets coincided with the themes that became evident in the videos and observation notes of the researcher. What was paramount for the participants was the opportunity for socialisation of the project, the development of appreciation for the two disciplines and for the whole creative process, personal growth and growth as an artist through the project. Among the four, appreciation and growth as an artist were the themes that tallied with those from the videos and observation notes.

The themes from the responses suggest that the collaboration project is an effective teaching approach for the connection between the two disciplines. Moreover, the project appears to have promoted holistic learning through the various activities and tasks that engaged the students in multidimensional ways and that involved faculties in all three domains of learning. This is evidenced by the students' creative output, showcased during the culminating activity. From the data collected through different instruments and from analyses of the findings, one may also conclude that aside from touching on the concepts of both disciplines, Poiesis also provides a venue for the students involved to grow as artists, to acquire a deeper appreciation for the arts and to develop values contributing to their growth as human beings. It offers its participants an enriching experience that helps them progress in their path to being full-fledged artists.

The results of this study show that the students primarily learned through Poiesis was appreciation for the subject areas, for the creative process and for each others' perspectives and interpretation. This appreciation stems from the hands-on experience of the concepts via the production of music and art and from the intercollegiate social interaction. We may infer that Poiesis is an effective teaching approach precisely because it was successful in bringing about a more enhanced learning. We may trace the success of the strategy back to the rationale behind curricular integration. Poiesis is an effective approach in teaching about the interrelatedness of the arts. It is a valuable resource for various contexts such as program or training sessions or for mentoring programs for in-service music and visual art teachers.

\section{References}

Balaban, O. (1990). Praxis and poiesis in Aristotle's practical philosophy. The Journal of Value Inquiry, 24, 185-198. Retrieved from https://link.springer.com/article/10.1007\%2FBF00149432

Bresler, L. (1995). The subservient, co-equal, affective and social integration styles of the arts. Arts Education Policy Review, 96(5), 31-37. Retrieved from http://www.tandfonline.com/doi/abs/10.1080/10632913.1995.9934564

Bresler, L. (2002). Harry Broudy on the cognitive merits of music education: Implications for research and practice of arts curriculum. Arts Education Policy Review, 103(3), 


\section{7-27. Retrieved from}

https://media.proquest.com/media/pq/classic/doc/110595002/fmt/pi/rep/NONE?cit\%3 Aauth $=$ Bresler\%2C+Liora\&cit\%3Atitle $=$ Harry+Broudy+on+the+cognitive+merits+o $\mathrm{f}+$ music+education $\% 3 \mathrm{~A}+$ Implications $+. . \& \mathrm{cit} \% 3 \mathrm{Apub}=$ Arts+Education+Policy+Revi ew

Bresler, L. (2011). Integrating the arts: Educational entrepreneurship in a school setting. Hellenic Journal of Music, Education, and Culture, 2(1), 5-17. Retrieved from http://r.search.yahoo.com/_ylt=A0SO8y4StHIZ03sAXHZXNyoA;_ylu=X3oDMTEy ZW9kMjJxBGNvbG8DZ3ExBHBvcwMxBHZ0aWQDQjQyNDVfMQRzZWMDc3I $/ \mathrm{RV}=2 / \mathrm{RE}=1501176978 / \mathrm{RO}=10 / \mathrm{RU}=\mathrm{http} \% 3 \mathrm{a} \% 2 \mathrm{f} \% 2$ fhejmec.eu $\% 2 \mathrm{fjournal} \% 2 \mathrm{findex}$ .php $\% 2 \mathrm{fHeJMEC} \% 2$ farticle $\% 2$ fdownload $\% 2 \mathrm{f} 33 \% 2 \mathrm{f} 26 / \mathrm{RK}=1 / \mathrm{RS}=04 \mathrm{ltCAWw} 53 \mathrm{p} 6$ M6dfuR7Ht7wd8c-

Campbell, P., \& Scott-Kassner, C. (2010). Music in childhood, $3^{\text {rd }}$ ed. Boston, MA: Schirmer Cengage Learning.

Coudriet, A. J. (2013). A multiple case study examining elementary school art, music and physical education teachers' perceptions, attitudes and beliefs related to interdisciplinary teaching practice (Doctoral Dissertation). Retrieved from https://search.proquest.com/central/docview/1433825119/fulltextPDF/3CA02BA4BD 1F4266PQ/1 ?accountid=173015

Creswell, J. W. (2012). Educational research: Planning, conducting, and evaluating quantitative and qualitative research, $4^{\text {th }} \mathrm{ed}$. Boston, MA: Pearson Education, Inc.

Galeazzi, C. (2015). The role of leadership in developing a successful arts integration school: A multi-site case study (Doctoral dissertation). Retrieved from https://media.proquest.com/media/pq/classic/doc/3868664761/fmt/ai/rep/NPDF?cit\% 3 Aauth=Galeazzi $\% 2 \mathrm{C}+$ Carlo\&cit $\% 3$ Atitle=The+role+of+leadership+in+developing+ a+successful+arts+integration..$+ \&$ cit\%3Apub=ProQuest+Dissertations+and+Theses

Government of the Republic of the Philippines. Department of Education. (2002).

MAKABAYAN Curriculum 2002. Retrieved from the Department of Education website: Retrieved from http://www.deped.gov.ph/sites/default/files/order/2002/DO_s2002_043.pdf

Government of the Republic of the Philippines. Department of Education. (2003). MAPEH Curriculum 2003. Retrieved from the Department of Education website: https://web.archive.org/web/20120308090421/http://www.deped.gov.ph/cpanel/uploa ds/issuancemg/DO\%2037_5-13-03_00001.pdf

Government of the Republic of the Philippines. Department of Education. (2013). K-12

Curriculum. Retrieved from the Department of Education website: http://www.deped.gov.ph/sites/default/files/page/2016/Music\%20CG.pdf

Greenberg, N. A. (1961). The use of poiema and poiesis. Harvard Studies in Classical Philology, 65, 263-289. Retrieved from https://www.jstor.org/stable/310839?seq=1\#page_scan_tab_contents

Hartle, L. C., Pinciotti, P., \& Gorton, R. L. (2015). ArtsIN: Arts integration and infusion framework. Early Childhood Education Journal, 43, 289-298. Retrieved from https://media.proquest.com/media/pq/classic/doc/3695849951/fmt/pi/rep/NONE?cit\% 3 Aauth $=$ Hartle $\% 2 \mathrm{C}+\mathrm{Lynn}+\mathrm{C} \% 3 \mathrm{BPinciotti} \% 2 \mathrm{C}+\mathrm{Patricia} \% 3 \mathrm{BGorton} \% 2 \mathrm{C}+$ Rebecca+ L\&cit\%3Atitle=ArtsIN

Huang, Y.T. (2012). Music integration in the elementary school community: An investigation of integration styles and collaborative modes in Pennsylvania and Taiwan. (Doctoral Dissertation). Retrieved from https://search.proquest.com/central/docview/873972905/fulltextPDF/BC60DACF8B7 84B5DPQ/1?accountid=173015 
Hulstrand, J. (2012). Curriculum integration: It's a marathon, not a sprint. International Educator, 21(5), 48-51. Retrieved from https://media.proquest.com/media/pq/classic/doc/2762967651/fmt/pi/rep/NONE?cit\% 3 Aauth $=$ Hulstrand $\% 2 \mathrm{C}+\mathrm{Janet} \& \mathrm{cit} \% 3 \mathrm{Atitle}=\mathrm{Curriculum}+$ Integration $\% 3 \mathrm{~A}+\mathrm{It} \% 27 \mathrm{~s}+\mathrm{a}$ +Marathon\%2C+Not+a+Sprint\&cit\%3Apub=International+Educator

Irwin, R. L., \& Reynolds, K. J. (1995). Integration as a strategy for teaching arts as disciplines. Arts Education Policy Review, 96(4). Retrieved from https://search.proquest.com/central/docview/211013995/fulltext/33D211D167EF47F $8 \mathrm{PQ} / 14$ ?accountid=173015

Jauss, H. R., \& Shaw, M. (1982). Poiesis. Critical Inquiry, 8(3), 591-608. Retrieved from https://philpapers.org/rec/JAUP-2

Lehmann, A. C., Sloboda, J. A., \& Woody, R. H. (2007). Psychology for musicians: Understanding and acquiring the skills. Oxford: Oxford University Press.

Marini, G. (2014). Aristotelic learning through the arts. Studies in Philosophy and Education, 33, 171-184. Retrieved from http://web.b.ebscohost.com/abstract?direct=true \&profile=ehost \&scope=site \&authtyp $\mathrm{e}=$ crawler $\& \mathrm{jnl}=00393746 \& \mathrm{AN}=94177484 \& \mathrm{~h}=\mathrm{W}$ winOdq8\%2b2IJp5ot\%2bJZ9kRsn5 qGaa5n\%2f44a7TEONfRA81dhAA5XLMFL9PnYIqauzWOFqjtYyusq1ULZ\%2bL7 $\mathrm{SpQ} \% 3 \mathrm{~d} \% 3 \mathrm{~d} \& \mathrm{crl}=\mathrm{c} \&$ resultNs$=$ AdminWebAuth\&resultLocal=ErrCrlNotAuth\&crlha shurl=login.aspx $\% 3$ fdirect $\% 3$ dtrue $\% 26$ profile $\% 3$ dehost $\% 26$ scope $\% 3$ dsite $\% 26$ authty pe\%3dcrawler\%26jrnl\%3d00393746\%26AN\%3d94177484

Marshall, J. (2010). Five ways to integrate: Using strategies from contemporary art. Art Education, 63(3), 13-19. Retrieved from https://media.proquest.com/media/pq/classic/doc/2042657051/fmt/pi/rep/NONE?cit\% 3 Aauth=Marshall $\% 2 \mathrm{C}+\mathrm{Julia} \& \mathrm{cit} \% 3 \mathrm{Atitle}=\mathrm{Five}+\mathrm{Ways}+\mathrm{to}+$ Integrate $\% 3 \mathrm{~A}+\mathrm{Using}+\mathrm{Str}$ ategies+from+Contemporary+Art\&cit $\% 3 \mathrm{Apub}=\mathrm{Art}+$ Education $\& \mathrm{cit} \% 3 \mathrm{Avol}=63 \& \mathrm{cit}$ $\% 3 \mathrm{Aiss}=3 \& \mathrm{cit} \% 3 \mathrm{Apg}=13 \& \mathrm{cit} \% 3$ Adate $=\mathrm{May}+2010 \& \mathrm{ic}=$ true $\&$ cit $\% 3 \mathrm{Aprod}=$ ProQues $\mathrm{t}+$ Central

Matusov, E., \& Marjanovic-Shane, A. (2012). Diverse approaches to education: Alienated learning, closed and open participatory socialization, and critical dialogue. Human Development, 55, 159-166. Retrieved from http://ematusov.soe.udel.edu/vita/Articles/Matusov, \%20MarjanovicShane, \%20Diverse\%20approaches\%20to\%20education,\%20HD,\%202012.pdf

Mosley, S. (2014). Effectiveness of integrating arts-based curriculum into the classroom. (Doctoral dissertation). Retrieved from . https://search.proquest.com/central/docview/1592005895/fulltextPDF/B210037F8D7 34B73PQ/1 ?accountid=173015

National Association for Music Education. (2014). NAfME Music Standards. Retrieved from National Association for Music Education website: https://nafme.org/myclassroom/standards/core-musicstandards/

Thompson, J. C. (2015). The student experience of arts integration: A phenomenological investigation. (Doctoral dissertation). Retrieved from https://search.proquest.com/docview/1696781708?pq-origsite=gscholar

Vazquez, O. M. (2014). An investigation of the teaching practices of music teaching artists participating in four selected elementary school arts integration projects (Doctoral Dissertation).Retrieved from. http://media.proquest.com/media/pq/classic/doc/3540868921/fmt/ai/rep/NPDF?_s=g TPrg24NpQNXMKihTe74o0jh\%2FBQ\%3D 
Whitehead, D. H. (2003). Poiesis and art-making: A way of letting-be. Contemporary Aesthetics, 1. Retrieved from http://www.contempaesthetics.org/newvolume/pages/article.php?articleID=216 Wiggins, R. (2001). Interdisciplinary curriculum: Music educator concerns. Music Educators Journal, 87(5), 40-44. Retrieved from https://eric.ed.gov/?id=EJ660145

\section{Biography}

Janel G. Bauza-Wahiman is an assistant professor at the College of Music of the University of the Philippines. She graduated with the degree of Master of Arts in Education, major in Curriculum Studies. 